\title{
IMPLEMENTASI SISTEM UJIAN ONLINE BERBASIS ANDROID: STUDI KASUS SMP YAMAD BEKASI
}

\author{
Andi Prastomo \\ Program Studi Informatika, Universitas Indraprasta PGRI Jakarta \\ andi_prastomo@ymail.com
}

Submitted January 26, 2020; Revised March 13, 2020; Accepted March 16, 2020

\begin{abstract}
Abstrak
Android merupakan sistem operasi berbasis Linux yang digunakan untuk perangkat seluler seperti telepon pintar (Smartphone) dan Tablet. Dikalangan pendidikan, penggunaan smartphone untuk ujian berbasis online dapat membantu proses ujian menjadi lebih mudah dan cepat, selain praktis dari segi pembuatan soal dan pengkoreksian jawaban, serta mampu mengurangi biaya pengeluaran seperti pengurangan penggunaan kertas maupun alat tulis. SMP Yamad Bekasi belum menerapkan sistem ujian online dengan perangkat smartphone berbasis android. Berdasarkan hal tersebut maka peneliti melakukan penelitian dengan tema Implementasi Sistem Ujian Online Berbasis Android dengan menggunakan metode penelitian Terapan (Apllied Research). Perancangan aplikasi menggunakan metode Waterfall dengan tahapan analisis menggunakan metode Requirement elicitation dan pengujian menggunakan metode Software Quality Assurance (SQA). Hasil dari penelitian ini lebih ditekankan pada tahap analisis kebutuhan sistem dengan metode Requirement Elicitation dengan hasil Final Draft Elicitation berupa poin-poin yang harus dimiliki oleh sistem yang akan dikembangkan, serta tahap pengujian sistem menggunakan metode Software Quality Assurance (SQA) dengan menghasilkan skor pengujian diatas nilai minimum rata-rata pengujian SQA yaitu 80.00 sehingga menghasilkan sistem yang memenuhi standar kualitas dengan baik dan layak untuk diimplementasikan dalam membantu proses ujian online pada SMP Yamad Bekasi.
\end{abstract}

Kata Kunci : Ujian online, Requirement elicitation, Software Quality Assurance

\begin{abstract}
Android is a Linux-based operating system used for mobile devices such as smartphones and tablets. In education sector, the use of smartphones for online-based exams can make the examination process easier and faster. In addition to being practical in terms of making questions and checking answers, using smartphones can also reduce expenses such as reducing the use of paper and stationery. Junior High School Yamad Bekasi has not implemented an online test system with an android-based smartphone device. Based on this, the researchers conduct research with the theme of Implementing the Android-Based Online Examination System using the Applied Research method. The application design uses the Waterfall method with Stages of Analysis with the Requirement elicitation method, while the test uses Software Quality Assurance (SQA) method. The results of this study emphasize more on the system requirements analysis stage with the Requirement Elicitation method with the Final Draft Elicitation results in the form of points that must be owned by the system to be developed, while the system testing stage uses the Software Quality Assurance (SQA) method with test scores above the minimum average value of SQA testing of 80.00 so that a system that meets the quality standards well and is feasible to be implemented in assisting the online examination process at SMP Yamad Bekasi can be produced.
\end{abstract}

Keywords : Online exams, Requirement elicitation, Software Quality Assurance.

\section{PENDAHULUAN}

Android merupakan sistem operasi berbasis Linux yang digunakan untuk perangkat seluler seperti telepon pintar
(Smartphone) dan Tablet [1]. Smartphone merupakan telepon pintar yang memiliki kemampuan layaknya komputer dalam bentuk yang ringkas dan dapat dibawa 
pergi kemanapun (mobile computing)[2]. Smartphone maupun tablet yang mengusung sistem operasi android merupakan perangkat mobile yang sudah sangat umum digunakan oleh seluruh lapisan masyarakat mulai dari kalangan anak-anak hingga lanjut usia. Dikalangan pendidikan, smartphone berguna untuk membantu proses belajar mengajar para siswa seperti contoh penggunaan sistem $e$ learning dan sejenisnya yang dapat diakses melalui perangkat smartphone, akan tetapi tidak semua instansi pendidikan sudah memanfaatkan smartphone dilingkungan pendidikan mereka.

SMP Yamad Bekasi merupakan yayasan pendidikan swasta yang berlokasi di Jl. Raya Pabuaran Jatisampurna kota Bekasi pertama kali berdiri dan beroperasi pada tahun 1982. SMP Yamad Bekasi belum menerapkan sistem untuk proses ujian mereka. semua proses ujian masih dilakukan secara manual menggunakan kertas dan alat tulis, serta proses pengkoreksian lembar jawaban dan penilaian guru pun masih dilakukan secara manual sehingga proses menjadi lama. melalui penelitian ini, peneliti memberikan solusi untuk membantu mempermudah proses ujian dengan mengimplementasikan aplikasi ujian online berbasis android, selain praktis dr segi pembuatan soal dan pengkoreksian jawaban, serta mampu mengurangi biaya pengeluaran seperti pengurangan penggunaan kertas maupun alat tulis.

Berdasarkan hal tersebut peneliti melakukan penelitian dengan tema Implementasi Sistem Ujian Online Berbasis Android dengan menggunakan metode penelitian terapan (Apllied Research). perancangan aplikasi menggunakan metode Waterfall dengan Tahapan Analisis menggunakan metode Requirement elicitation dan pengujian menggunakan metode Software Quality Assurance (SQA) sehingga sistem yang dikembangkan mampu memenuhi standar kualitas dengan baik dan sesuai kebutuhan guna membantu proses pengolahan data ujian online SMP Yamad Bekasi.

Elisitasi merupakan suatu metode yang digunakan untuk menganalisa kebutuhan rekayasa perangkat lunak yang memiliki definisi sekumpulan aktifitas yang dilakukan untuk mencari kebutuhan suatu sistem yang baru melalui komunikasi dengan pelanggan dan pihak terkait yang dengan kepentingan dengan pengembangan system[3]. Elisitasi merupakan sebuah rancangan yang diciptakan sesuai dengan keinginan oleh pihak manajemen terkait yang disanggupi oleh peneliti untuk selanjutnya dieksekusi[4] .

Elisitasi diperoleh melalui proses wawancara yang kemudian diproses melalui tiga tahapan yaitu : (1) Elisitasi Tahap I, Berisi seluruh data kebutuhan sistem baru yang diusulkan oleh pihak manajemen terkait dari hasil wawancara; (2) Tahap II, Merupakan hasil dari pengklasifikasian proses elisitasi tahap I yang selanjutnya di proses dengan metode MDI, Metode MDI bertujuan untuk memisahkan antara kebutuhan sistem yang penting dan harus ada dengan rancangan yang disanggupi oleh peneliti untuk dieksekusi dimana M berarti Mandatory (penting) merupakan kebutuhan yang harus ada dan tidak boleh dihilangkan, $\mathrm{D}=$ Desireable yang merupakan kebutuhan tidak terlalu penting dan boleh dihilangkan namun membuat sistem kurang sempurna, $\mathrm{I}=$ Inessential merupakan kebutuhan yang bukan termasuk bagian sistem dibahas; (3) Tahap III, Merupakan proses penyusutan data dari hasil tapah II dengan cara mengeliminasi semua kebutuhan sistemn dengan option I pada metode MDI. Selanjutnya semua requirement yang tersisa diklasifikasikan kembali dengan metode TOE, yaitu : T artinya Technical, maksudnya bagaimana tata cara / teknik 
pembuatan requirement tersebut dalam sistem yang diusulkan, $\mathrm{O}$ artinya Operational, maksudnya bagaimana tata cara penggunaan requirement tersebut dalam sistem yang akan dikembangkan, $\mathrm{E}$ artinya Economi, maksudnya berapakah biaya yang diperlukan guna membangun requirement tersebut didalam sistem. [5]

Software Quality Assurance (SQA) adalah "suatu metode pengujian perangkat lunak yang bertujuan untuk menghasilkan suatu produk perangkat lunak (software) yang berkualitas tinggi.[6] SQA merupakan salah satu aktivitas yang harus dijalani dalam suatu proses pengembangan software." Ada 8 buah kriteria yang digunakan untuk mengukur kualitas sebuah perangkat lunak menggunakan SQA, yaitu : Auditabilit (pemenuhan standard), Accuracy (keakuratan software), Completeness (kelengkapan), Error Tolerance (toleransi terhadap kesalahan), Execution Efficiency (kinerja eksekusi), Operability (kemudahan untuk dioperasikan). Simplicity (kemudahan untuk dipahami), Training (kemudahan pembelajaran dengan fasilitas help)[7].

\section{METODE PENELITIAN}

Penelitian yang dilakukan peneliti berlokasi di SMP Yamad Bekasi. Jenis penelitian ini merupakan penelitian terapan (Apllied Research). Penelitian Terapan merupakan penelitian yang hasilnya dapat diterapkan secara langsung guna memecahkan permasalahan yang ada [8].

Penelitian ini menerapkan langkah-langkah pengembangan sistem dengan model pengembangan sistem Waterfall, yang terdiri dari tahapan Analisis menggunakan Metode pendekatan Elisitasi (Requirement elicitation), Tahapan desain menggunakan UML, Implementasi yang terdiri dari pengkodean menggunakan bahasa pemrograman Java dan Tahap Pengujian menggunakan metode Software Quality Assurance (SQA).
Model waterfall atau sering disebut siklus hidup klasik (Classic Life Cycle), merupakan model pendekatan secara sistematis dan berurutan (sekuensial) pada proses pengembangan perangkat lunak, diawali dengan spesifikasi kebutuhan user / pengguna, lalu tahap perencanaan, pemodelan, kemudian konstruksi, dan penyerahan sistem ke pengguna (deployment) [9].

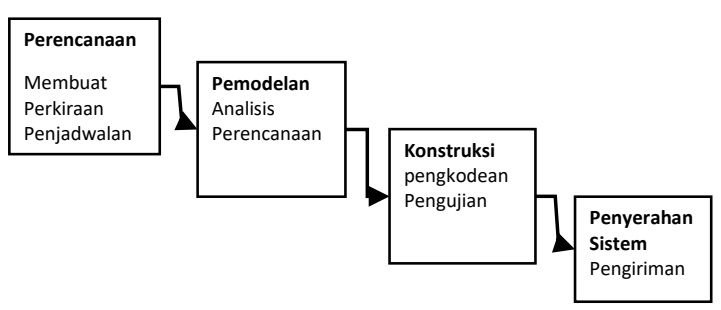

Gambar 1. Model Waterfall [10]

\section{Metode Pemilihan Sampel}

Pengambilan sampel pada penelitian ini menggunakan metode Purposive sampling. purposive sampling merupakan teknik untuk pengambilan sampel dengan memilih responden berdasarkan ciri-ciri spesifik sampel yang ditentukan oleh peneliti.

Responden dalam penelitian ini terdiri dari Kepala Sekolah beserta wakilnya dan guruguru serta para murid. Responden sampel yang dipilih merupakan responden yang terlibat dalam sistem yang dikembangkan dan diimplementasikan.

\section{Metode Pengumpulan Data}

Untuk mengumpulkan data dan informasi yang dibutuhkan, Metode yang digunakan peneliti sebagai berikut :

a. Wawancara (Interview)

Data yang dikumpulkan didapat dengan proses tanya jawab langsung kepada kepala sekolah beserta wakilnya dan para guru.

b. Kuesioner

Pengumpulan data yang didapat dengan teknik pembagian daftar pertanyaan secara langsung kepada Kepala sekolah, wakil kepala sekolah, 
guru-guru dan siswa yang selanjutnya diproses untuk menggambarkan tingkat kebutuhan sistem yang akan dikembangkan serta pengujian sistem.

c. Metode Observasi

Pengumpulan data dengan cara mengamati secara langsung objek penelitian di lokasi studi kasus SMP Yamad Bekasi.

\section{Teknik Analisa Data}

Pada Tahapan Analisa dari Metode waterfall yang digunakan peneliti yaitu menggunakan metode Requirement elicitation untuk menganalisa data-data kebutuhan sistem yang akan dikembangkan. Elisitasi diperoleh melalui proses wawancara yang hanya melibatkan Stakeholder yang dimana stakeholder disini merupakan kepala sekolah yang mewakili seluruh guru.

a. Langkah-langkah Penelitian

Penelitian dilaksanakan dalam waktu 4 bulan dengan tahapan sebagai berikut :

1) Survey

survey dilakukan dengan

melakukan pengamatan tinjauan dilokasi penelitian di SMP Yamad Bekasi.

2) Analisa

Tahapan ini dilakukan proses pengidentifikasian permasalahanpermasalahan yang ada pada SMP Yamad Bekasi sehingga mendapatkan suatu permasalahan sistem yang ada lalu melakukan analisa kebutuhan sistem menggunakan teknik Requirement elicitation.

3) Desain Sistem

Pada tahapan ini dilakukan desain rancangan sistem sebagai solusi dari masalah yang dihadapi menggunakan UML.

4) Pengkodean Sistem

Pada tahap pengkodean ini dilakukan pembuatan sistem dengan menggunakan bahasa pemrograman Java dengan editor Visual Studio

5) Pengujian

Pada tahapan ini dilakukan pengujian sistem yang sudah dikembangkan menggunakan metode Software Quality Assurance (SQA) sehingga sistem yang telah dikembangkan dapat berfungsi dengan baik sesuai dengan kebutuhan. pengguna.

6) Kesimpulan

Membuat kesimpulan dan saran dari penelitian yang telah dilakukan

\section{HASIL DAN PEMBAHASAN Analisa Kebutuhan Sistem}

Tahap analisa kebutuhan sistem ujian online ini menggunakan metode Requirement elicitation yang diproses berdasarkan keinginan client yang mampu di sanggupi oleh peneliti dengan melalui beberapa tahapan diantaranya :

Recuirement Elicitation Tahap 1 :

Pada tahap ini terdapat seluruh kebutuhan sistem yang didapat dari pihak Stekaholder terkait melalui proses wawancara.

Tabel 1. Elicitation Tahap I

\begin{tabular}{|l|l|}
\hline \multicolumn{2}{|c|}{ Functional } \\
\hline \multicolumn{2}{|c|}{ Analisa Kebutuhan ingin sistem dapat : } \\
\hline \multicolumn{2}{|c|}{ Sayap Guru memiliki akun sendiri } \\
\hline 1. & Setiap \\
\hline 2. & Guru dapat mengupload bahan ujian \\
\hline 3. & Guru dapat membuat soal ujian online \\
\hline 4. & Guru dapat membatasi peserta ujian \\
\hline 5. & Guru dapat melihat riwayat ujian \\
\hline 6. & Guru dapat menentukan waktu ujian online \\
\hline 7. & Guru memiliki ruang forum sendiri \\
\hline 8 & Guru dapat Melihat hasil ujian \\
\hline 9. & Setiap siswa dapat mendaftar dan memiliki akun sendiri \\
\hline 10. & Siswa dapat mengunduh bahan ujian \\
\hline 11. & Siswa dapat melihat notifikasi waktu ujian \\
\hline 12. & Siswa dapat mengikuti ujian online \\
\hline 13. & Siswa dapat melihat nilai secara online \\
\hline 14. & Siswa memiliki raport hasil ujian keseluruhan \\
\hline 15. & Siswa dapat mengikuti forum guru \\
\hline 16. & Siswa dapat melihat riwayat seluruh ujian \\
\hline 17. & Sistem dapat mengkoreksi jawaban secara otomatis \\
\hline 18. & $\begin{array}{l}\text { Sistem dapat membuat nilai dan raport siswa secara } \\
\text { otomatis }\end{array}$ \\
\hline 19. & Sistem memiliki fitur live chat / chat room \\
\hline 20. & Sistem dapat menampilkan siapa saja yang online \\
\hline 21. & Sistem dapat menampilkan informasi dan berita sekolah \\
\hline 22. & System menampilkan berita seputar pendidikan \\
\hline 23. & Sistem dilengkapi fitur video-video hiburan \\
\hline
\end{tabular}




\section{Requirement elicitation Tahap II :}

Elisitasi pada tahap II dilakukan proses pengklasifikasian data dari Tahap I melalui teknik MDI dengan opsi Inessential (I) yang wajib dieliminasi diantaranya :

Tabel 2. Requirement elicitation Tahap II

\begin{tabular}{|c|c|c|c|c|}
\hline \multicolumn{5}{|c|}{ Functional } \\
\hline \multicolumn{5}{|c|}{ Analisa Kebutuhan } \\
\hline \multicolumn{5}{|c|}{ Saya ingin sistem dapat : } \\
\hline & & M & D & I \\
\hline 1. & Setiap Guru memiliki akun sendiri & $\checkmark$ & & \\
\hline 2. & Guru dapat mengupload bahan ujian & & $\checkmark$ & \\
\hline 3. & Guru dapat membuat soal ujian online & $\checkmark$ & & \\
\hline 4. & Guru dapat membatasi peserta ujian & & $\checkmark$ & \\
\hline 5. & Guru dapat melihat riwayat ujian & $\checkmark$ & & \\
\hline 6. & $\begin{array}{l}\text { Guru dapat menentukan waktu ujian } \\
\text { online }\end{array}$ & $\checkmark$ & & \\
\hline 7. & Guru memiliki ruang forum sendiri & & & $\checkmark$ \\
\hline 8 & Guru dapat Melihat hasil ujian & $\checkmark$ & & \\
\hline 9. & $\begin{array}{l}\text { Setiap siswa dapat mendaftar dan } \\
\text { memiliki akun sendiri }\end{array}$ & $\checkmark$ & & \\
\hline 10 & Siswa dapat mengunduh bahan ujian & & $\checkmark$ & \\
\hline 11 & Siswa dapat melihat notifikasi waktu ujian & $\checkmark$ & & \\
\hline 12 & Siswa dapat mengikuti ujian online & $\checkmark$ & & \\
\hline 13 & $\begin{array}{l}\text { Siswa dapat melihat hasil ujian secara } \\
\text { online }\end{array}$ & $\checkmark$ & & \\
\hline 14 & $\begin{array}{l}\text { Siswa memiliki raport hasil ujian } \\
\text { keseluruhan }\end{array}$ & $\checkmark$ & & \\
\hline 15 & Siswa dapat mengikuti forum guru & & & $\checkmark$ \\
\hline 16 & Siswa dapat melihat riwayat seluruh ujian & $\checkmark$ & & \\
\hline 17 & $\begin{array}{l}\text { Sistem dapat mengkoreksi jawaban secara } \\
\text { otomatis }\end{array}$ & $\checkmark$ & & \\
\hline 18 & $\begin{array}{l}\text { Sistem dapat membuat nilai dan raport } \\
\text { siswa secara otomatis }\end{array}$ & $\checkmark$ & & \\
\hline 19 & Sistem memiliki fitur live chat / chat room & & & $\checkmark$ \\
\hline 20 & $\begin{array}{l}\text { Sistem dapat menampilkan siapa saja yang } \\
\text { online }\end{array}$ & & & $\checkmark$ \\
\hline 21 & $\begin{array}{l}\text { Sistem dapat menampilkan informasi dan } \\
\text { berita sekolah }\end{array}$ & & & $\checkmark$ \\
\hline 22 & $\begin{array}{l}\text { System menampilkan berita seputar } \\
\text { pendidikan }\end{array}$ & & & $\checkmark$ \\
\hline 23 & $\begin{array}{l}\text { Sistem dilengkapi fitur video-video } \\
\text { hiburan }\end{array}$ & & & $\checkmark$ \\
\hline
\end{tabular}

\section{Requirement elicitation Tahap III :}

Elisitas tahap III dilakukan proses pengklasifikasian dari data tahap II menggunakan teknik TOE dengan opsi LMH.

\section{Tabel 3 Requirement elicitation Tahap III}

\begin{tabular}{|l|l|c|c|c|c|c|c|c|c|c|}
\hline \multicolumn{2}{|l|}{ Feasibility } & \multicolumn{3}{|c|}{ T } & \multicolumn{3}{c|}{ O } & \multicolumn{3}{c|}{ E } \\
\hline Risk & L & M & H & L & M & H & L & M & H \\
\hline 1. & $\begin{array}{l}\text { Setiap Guru } \\
\text { memiliki akun } \\
\text { sendiri }\end{array}$ & $\checkmark$ & & & $\checkmark$ & & & $\checkmark$ & & \\
\hline 2. & $\begin{array}{l}\text { Guru dapat } \\
\text { mengupload } \\
\text { bahan ujian }\end{array}$ & $\checkmark$ & & & & & $\checkmark$ & & & $\checkmark$ \\
\hline 3. & $\begin{array}{l}\text { Guru dapat } \\
\text { membuat soal } \\
\text { ujian online }\end{array}$ & $\checkmark$ & & & & $\checkmark$ & & $\checkmark$ & & \\
\hline
\end{tabular}

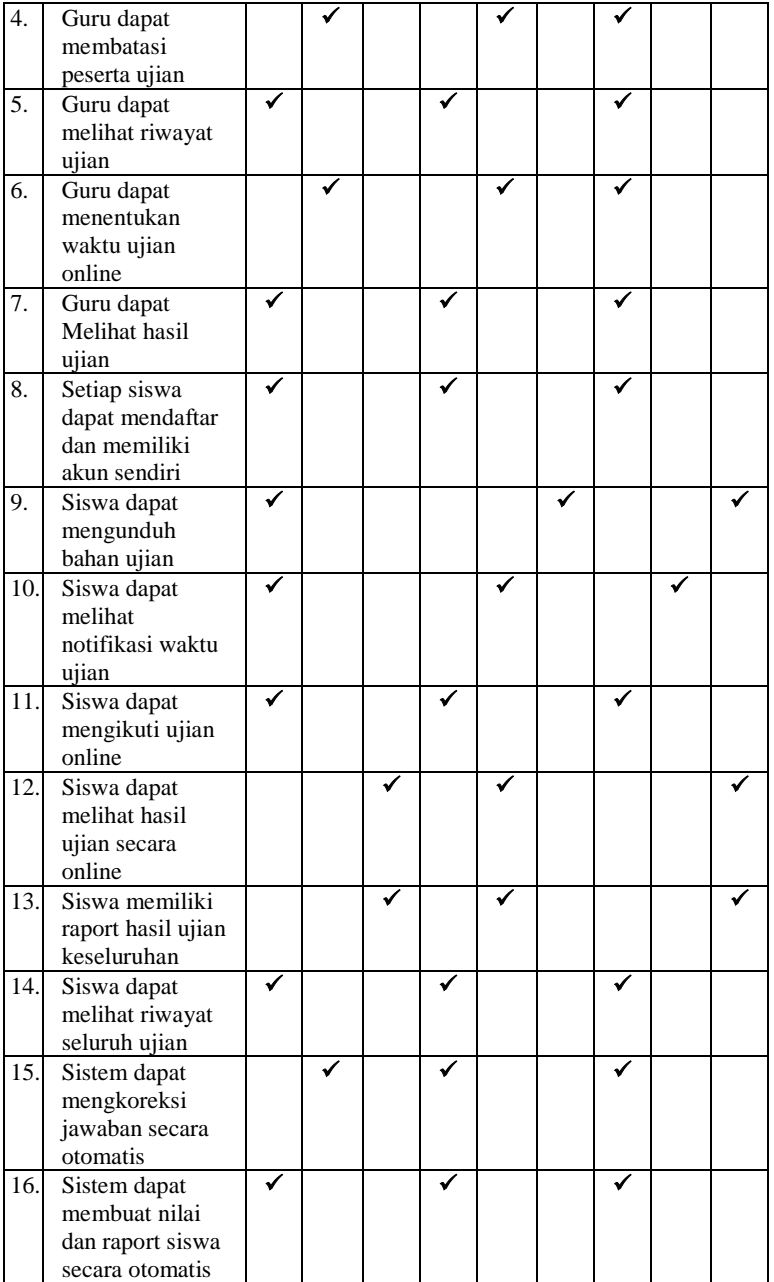

Final Draft Elisitasi :

Tahapan akhir metode Requirement elicitation adalah Final Draft yang berisi kesimpulan kebutuhan sistem yang nantinya digunakan sebagai acuan dalam pengembangan aplikasi ujian online :

Tabel 4. Requirement elicitation Tahap II

\begin{tabular}{|l|l|}
\hline \multicolumn{2}{|l|}{ Functional } \\
\hline \multicolumn{2}{|c|}{ Analisa Kebutuhan } \\
\hline \multicolumn{2}{|c|}{ Saya ingin sistem dapat : } \\
\hline 1. & Setiap Guru memiliki akun sendiri \\
\hline 2. & Guru dapat membuat soal ujian online \\
\hline 3. & Guru dapat membatasi peserta ujian \\
\hline 4. & Guru dapat melihat riwayat ujian \\
\hline 5. & Guru dapat menentukan waktu ujian online \\
\hline 6. & Guru dapat Melihat hasil ujian \\
\hline 7. & $\begin{array}{l}\text { Setiap siswa dapat mendaftar dan memiliki akun } \\
\text { sendiri }\end{array}$ \\
\hline 8. & Siswa dapat melihat notifikasi waktu ujian \\
\hline
\end{tabular}


\begin{tabular}{l|l}
9. & Siswa dapat mengikuti ujian online \\
\hline
\end{tabular}

\begin{tabular}{l|l} 
10. Siswa dapat melihat hasil ujian secara online \\
\hline 11.
\end{tabular}

11. Siswa memiliki raport hasil ujian keseluruhan

\begin{tabular}{c|l}
12. & Siswa dapat melihat riwayat seluruh ujian \\
\hline 13 & Sistem dapat mengkoreksi jawaban secara ot
\end{tabular}

13. Sistem dapat mengkoreksi jawaban secara otomatis

14. Sistem dapat membuat nilai dan raport siswa secara otomatis

Berdasarkan Final Draft pada metode requirement elicitation diatas maka menghasilkan data-data kebutuhan sistem yang kemudian dijadikan acuan dalam proses pengembangan sistem ujian online di tahap pengkodean dengan melibatkan 3 Aktor diantaranya Admin, Guru dan Siswa.

\section{Desain Sistem}

Proses Desain sistem dilakukan guna menjelaskan interaksi antara sistem dengan dunia luar seperti actor secara fungsionalitas melalui pemodelan diagram use case.didalam desain use case sistem ini melibatkan tiga actor yaitu : Administrator, guru, dan Siswa dimana setiap actor memiliki hak asesnya masing-masing, seperti pada gambar berikut :

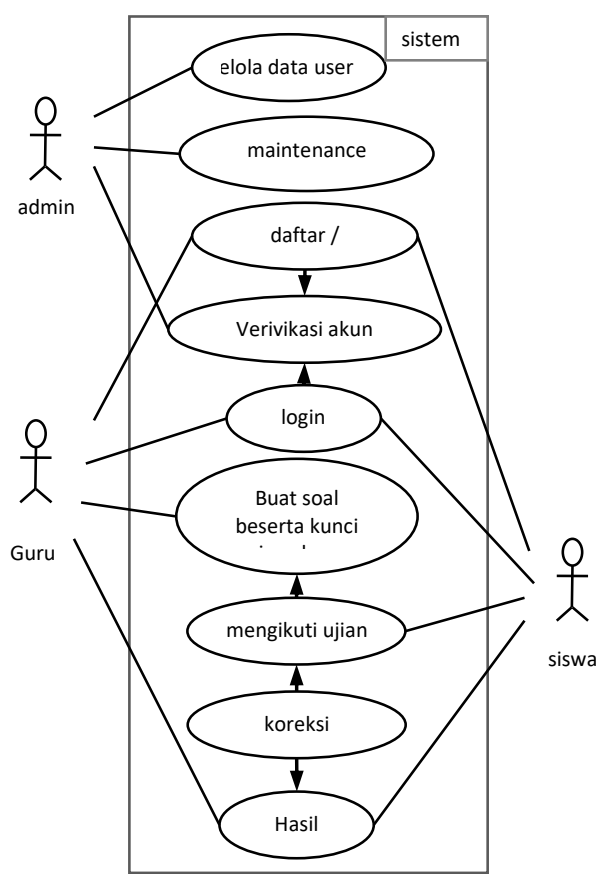

Gambar 2.Use Case Diagram

Pada gambar use case diagram diatas terdapat 3 orang aktor diantaranya Admin sebagai pengelola sistem, guru sebagai pengelola data ujian online, dan siswa sebagai user yang mengikuti ujian online

\section{Antarmuka Sistem}

Tahapan pengkodean sistem pada model Waterfall menghasilkan aplikasi ujian online berbasis android dengan tampilan antarmuka sebagai berikut :

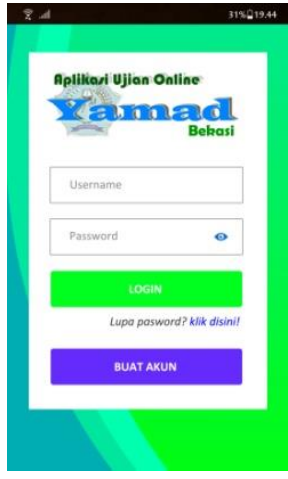

Gambar 3. Login

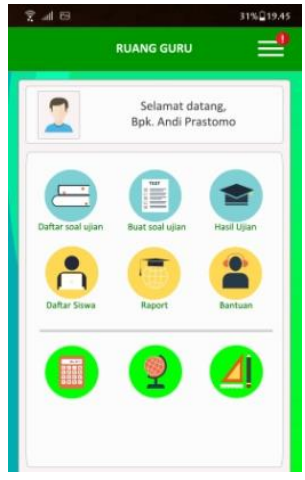

Gambar 4. Halaman Guru
Pada Gambar 3 terdapat form login yang bisa digunakan untuk login guru dan siswa, serta terdapat menu Buat Akun untuk pengguna baru dan pada gambar 4 terdapat Halaman Guru ketika guru sudah berhasil login, didalamnya terdapat menumenu untuk mengelola soal dan hasil ujian online.

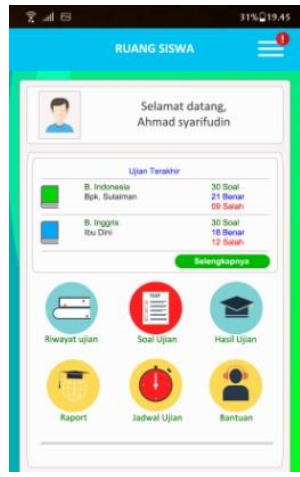

Gambar 5. Halaman Siswa

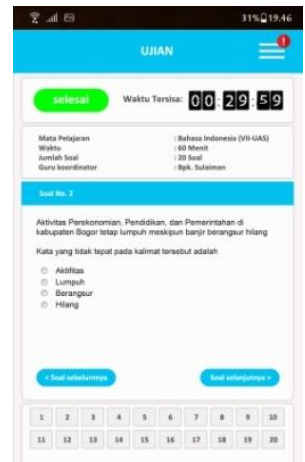

Gambar 6. Halaman Ujian
Pada Gambar 5 terdapat Halaman siswa ketika siswa sudah berhasil login dengan akunnya, didalamnya terdapat menu-menu untuk mengikuti ujian online dan melihat nilai serta riwayat ujian online yang diikuti 
sementara pada Gambar 6 terdapat halaman ujian online ketika siswa mengikuti ujian online.

\section{Pengujian Sistem}

Tahap selanjutnya pada model Waterfall ialah Tahap Pengujian sistem, pada tahap ini memastikan sistem sesuai kebutuhan dan menghasilkan sistem yang berkualitas menggunakan metode pengujian SQA (Software Quality Assurance).

Proses pengujian dilakukan dengan menghadiri 5 orang responden yang terdiri dari pemilik kepala sekolah, wakil kepala sekolah, 1 orang guru, dan 2 orang siswa yang terlebih dahulu mencoba sistem yang dikembangkan dan dilanjut dengan mengisi pertanyaan kuesioner dengan rincian sebagai berikut :

Tabel 5. Responden Survey SQA

\begin{tabular}{|l|l|c|}
\hline No & \multicolumn{1}{|c|}{ Responden Survey } & JUMLAH \\
\hline 1. & Kepala Sekolah & 1 \\
\hline 2. & Wakil Kepala Sekolah & 1 \\
\hline 3. & Guru & 1 \\
\hline 4. & Siswa & 2 \\
\hline \multicolumn{2}{|c|}{ TOTAL } & 5 \\
\hline
\end{tabular}

Tabel 6. Rincian Metric dari Software Quality Assurance (SQA)

\begin{tabular}{|r|l|l|c|}
\hline No & \multicolumn{1}{|c|}{ Metrik } & Deskripsi & Bobot \\
\hline 1 & Auditability & $\begin{array}{l}\text { Standar terpenuhi atau } \\
\text { tidak }\end{array}$ & 0.125 \\
\hline 2 & Accuracy & $\begin{array}{l}\text { Keakuratan komputasi } \\
\text { sistem }\end{array}$ & 0.125 \\
\hline 3 & Completeness & $\begin{array}{l}\text { Kelengkapan fitur } \\
\text { sistem }\end{array}$ & 0.125 \\
\hline 4 & $\begin{array}{l}\text { Error } \\
\text { Tolerance }\end{array}$ & $\begin{array}{l}\text { Toleransi terhadap } \\
\text { kesalahan atau bugs }\end{array}$ & 0.125 \\
\hline 5 & $\begin{array}{l}\text { Execution } \\
\text { Efficiency }\end{array}$ & $\begin{array}{l}\text { Kinerja pemrosesan / } \\
\text { Eksekusi }\end{array}$ & 0.125 \\
\hline 7 & Operability & $\begin{array}{l}\text { Kemudahan dalam } \\
\text { penggunaan }\end{array}$ & 0.125 \\
\hline 8 & Simplicity & $\begin{array}{l}\text { Kemudahan untuk } \\
\text { dimengerti }\end{array}$ & 0.125 \\
\hline
\end{tabular}

Berikut rincian perhitungan berdasarkan nilai dari 6 responden pengguna, dengan menggunakan rumus SQA sebagai berikut:
Skor $=\quad\langle$ SkorAuditability $\rangle * 0.125+$

$<$ SkorAccuracy $>* 0.125$

$\langle$ SkorErrorTolerance $\rangle * 0.125+$

$<$ SkorExecutionEfficiency $>\quad * 0.125+$

$\begin{array}{lll}\langle\text { SkorOperability }\rangle^{*} & 0.125+\end{array}$

$<$ SkorSimplicity ${ }^{*} \quad 0.125 \quad+$

$<$ SkorTraining $>* 0.125$

Tabel 7. Hasil Pengujian Metode Software Quality Assurance (SQA)

\begin{tabular}{|c|c|c|c|c|c|c|c|c|c|}
\hline \multirow{2}{*}{ User } & \multicolumn{8}{|c|}{ Skor Metrik } & \multirow{2}{*}{ Skor } \\
\hline & 1 & 2 & 3 & 4 & 5 & 6 & 7 & 8 & \\
\hline$\# 1$ & 77 & 76 & 77 & 77 & 87 & 72 & 87 & 71 & 78 \\
\hline$\# 2$ & 79 & 78 & 79 & 83 & 86 & 84 & 75 & 80 & 80.5 \\
\hline$\# 3$ & 79 & 87 & 83 & 77 & 83 & 81 & 80 & 80 & 81.25 \\
\hline \#4 & 75 & 74 & 86 & 80 & 78 & 79 & 80 & 88 & 80 \\
\hline$\# 5$ & 79 & 80 & 76 & 77 & 85 & 80 & 86 & 81 & 80.5 \\
\hline \multicolumn{9}{|c|}{ Rata-Rata } & 80.05 \\
\hline
\end{tabular}

Berdasarkan hasil pengujian sistem menggunakan metode SQA terhadap 5 orang responden melalui kuesioner yang diberikan dengan 8 butir pertanyaan yang mencakup metrik Auditability, Accuracy, Completness, Error Tolerance, Execution Efficiency, Operability, Simplycity, dan Training maka menghasilkan kesimpulan dengan nilai rata-rata sebesar 80, 05, dimana skor tersebut memenuhi standar kualitas sistem menurut metode SQA dengan skor standar minimum yaitu 80.00.

\section{SIMPULAN}

Simpulan dari penelitian yang dilakukan oleh peneliti ini menghasilkan sebuah sistem ujian online berbasis android yang layak untuk diimplementasikan oleh SMP Yamad Bekasi dengan proses tahap analisis kebutuhan sistem menggunakan metode Requirement Elicitation sehingga menghasilkan point-point kebutuhan sistem yang dijadikan acuan dalam pengembangan sistem dan pengujian sistem menggunakan metode Software Quality Assurance (SQA). Dengan melibatkan 5 responden terpilih yang terdiri dari kepala sekolah, wakil kepala 
sekolah, 1 orang guru, dan 2 orang Siswa menghasilkan Skor rata-rata SQA sebesar 80.05 sehingga menyimpulkan bahwa sistem ujian online yang diimplementasikan dapat berfungsi dengan baik sesuai standar kualitas SQA sehingga bermanfaat untuk membantu proses ujian online berbasis android pada SMP Yamad Bekasi.

\section{DAFTAR PUSTAKA}

[1] T. Listyorini and A. Widodo, "Perancangan Mobile Learning Mata Kuliah Sistem Operasi Berbasis Android," Simetris J. Tek. Mesin, Elektro dan Ilmu Komput., 2013.

[2] A. A. Leiman, A. Handojo, and A. Noertjahyana, "Aplikasi Ujian Online Pada Mobile Device Android," J. Infra, 2013.

[3] I. Sommerville, Software engineering (10th edition). 2016.

[4] F. Adikara, H. Gunawan, and S. Sandfreni, "Pemodelan Hasil Elisitasi Kebutuhan Sistem Penjualan Online Menggunakan Metode Knowledge Acquisition in Automated Specification," $J$. Edukasi dan Penelit. Inform., 2018.
[5] T. Iqbal, "Requirement Elicitation Technique : - A Review Paper," Int. J. Comput. Math. Sci., 2014.

[6] S. Alfarisi, "Sistem E - Learning Berbasis Knowledge Management Pada SMK Generasi Madani Cibinong," J. SISFOTEK Glob., 2017.

[7] D. Galin, Software Quality Assurance: Concepts and Practice. 2017.

[8] A. Jaedun, "Metodologi penelitian eksperimen," Metodol. Penelit. Eksperimen, 2011.

[9] P. D. Roger S. Pressman, "Rekayasa Perangkat Lunak - Buku Satu, Pendekatan Praktisi," in Software Engineering: A Practitioner's Approach, Seventh Edition, 2012.

[10] M. Tabrani and E. Pudjiarti, "Penerapan Metode Waterfall Pada Sistem Informasi Inventori Pt. Pangan Sehat Sejahtera," J. Inkofar *, 2017. 